\title{
八茎鉱山
}

\section{Yaguki Mine}

正会員田䢞次 毁米

\section{1. 緒言}

八茎鉱山は福島県いわき市四倉町内にあり，常磐線四 含駅の北西約 $11 \mathrm{~km}$ ○地点江事務所, 選鉱場, 通洞坑口 がある。四倉駅より玉山まで専用線 $6 \mathrm{~km}$ が住友セメン トによつて敷設してあり，玉山から鉣業所までの $5 \mathrm{~km}$ は幅 6 mの産業道路を有する。

当鉱山の発見は遠く明徳 2 年（約1,200年前）乙いわ れ，天正年間上り原始的な手掘りによつて採掘されてい たと伝えられている。その後幾多の変爵を経て昭和 29 年
第 1 表 生産実績

\begin{tabular}{|c|c|c|}
\hline \multirow{2}{*}{$\begin{array}{c}\text { 粗銥量 } \\
(\mathrm{t})\end{array}$} & 品 & 位 \\
\hline & $\mathrm{Cu} \%$ & $\mathrm{Fe} \%$ \\
\hline 46,074 & 0.77 & 4.44 \\
\hline
\end{tabular}

第 2 表 従業員

\begin{tabular}{|c|c|c|c|c|}
\hline & & 坑内 & 坑 外 & 部 \\
\hline $\begin{array}{l}\text { 職 } \\
\text { 随 } \\
\text { 臨時 }\end{array}$ & 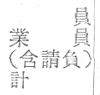 & $\begin{array}{l}16 \\
125 \\
174 \\
315\end{array}$ & $\begin{array}{r}13 \\
47 \\
62 \\
122\end{array}$ & $\begin{array}{r}29 \\
-172 \\
236 \\
437\end{array}$ \\
\hline
\end{tabular}

注：昭和 42 年 3 貝現在の採鉣, 選鉱, 鉱床探查の従業員数

日鉄鉱業が鉱羓権を買収し，同30年に八茎鉣 山調查事務所を設け，鋭意探鉣の結果，優勢 な銅鉱床の賦存索確認し 32 年に八茎鉱業所上

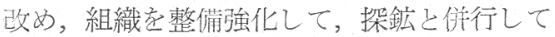
開発に着手した。

すなわ方，33年7月葛蒲平 $230 \mathrm{~mL}$ 亿約

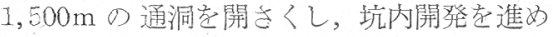
るとともに，33年10月粗鉱200t/日処理の選 鉱パイロットプラントを完成し，試験操業老 開始した。その後探鉱の結果, 約 700 万 $\mathrm{t}$ の 鉱量を確認したので，34年開発基本計画を策 定し，坑内切羽の準備に努好るとともに，35 年に 500 t/日の選鉣プラントを增設して，36 年より $900 \mathrm{t} /$ 日処理の操業に入つた。さらに 探鉱の進展に伴なつて鉱量が増加したので, 36年下期に $500 t /$ 日 選鉱プラントの増設に 着手し，37年4月にこれを完成し，1,300t/ 日処理操業孛経て現在 $1,700 \mathrm{t} /$ 日 の処理操業 を実筂している。

な拉，40年 7 月より延長 $5,000 \mathrm{~m}$ におよぶ 玉山探鉱坑道掘進を坑外より開始し，42年 6 月に坑内 $80 \mathrm{~mL}$ L貫通の予定である。

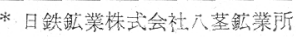

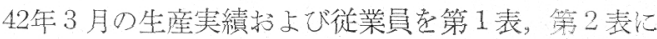
示吉。

\section{2. 地質・鉱床の概要}

鉱山付近の地質は，主に結晶片岩類おくび酸性深成岩 類よりなる阿武郎山地の東南端に位する時代未祥の古生 層よりなり，鉱床はこのほぼ中央に位する。古生層は上 下 2 層に大别され，下部海閃片岩，雲母片岩，緑泥片 岩の互層で，上部恃粘板岩，石灰岩，砂岩，礫岩，輝緑 凝灭岩等の互層よりなり，去の走行注緑青沢上流ででN

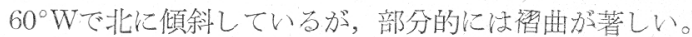
特に緑青沢下流付近では，南北方向の軸老有する问斜構

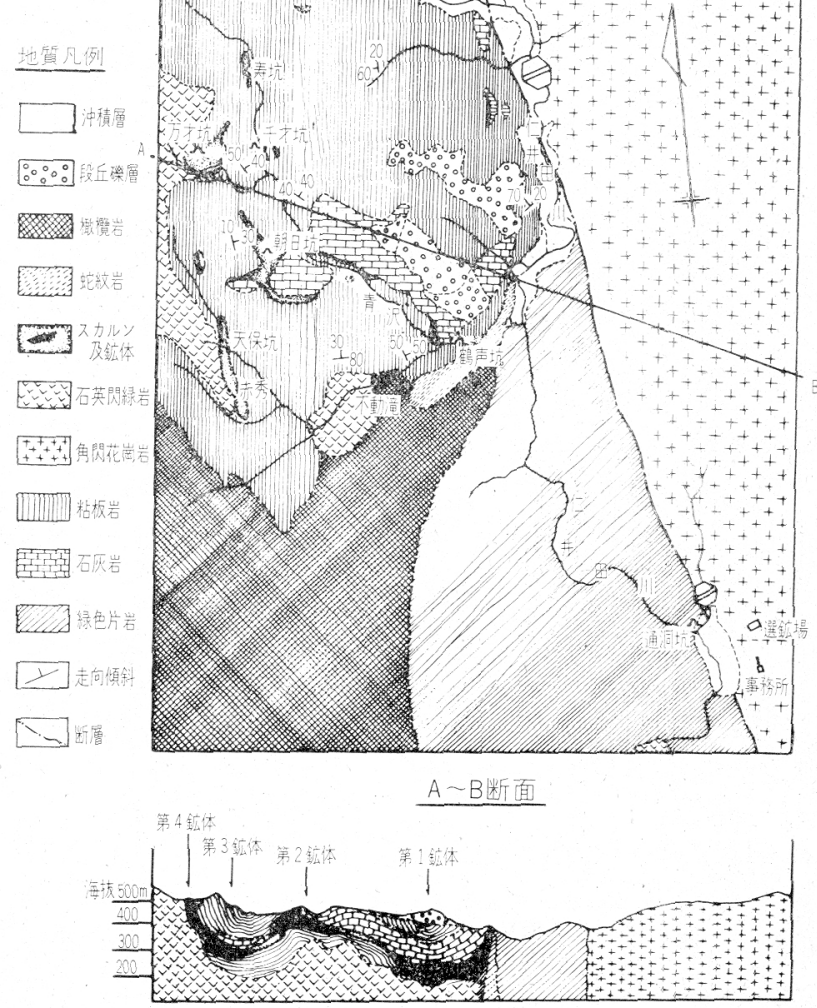

第1図 八茎鉱山地質図 
造と，さらにこれと隣接し西側に背斜構造と向斜構造が 見られる。南北に長く延びる玉山断層の東側には花崗閃 緑岩が広大な露出をなし，古生層の西方地域にも花崗閃 緑岩が分布している。古生層は花崗閃緑岩の迸入によつ て接触変成ならびに変質を受け，粘板岩はホルンフェル スに変り，石灰岩はその下盤が特に著しいスカルン化作 用によつて一大スカルン帯を形成している。鉱化作用は 特に向斜または背斜軸に沿つて顕著である。

鉱床は，本邦における典型的な銅の接触交代鈗床で， 上記スカルン帯中に胚胎し，形状は不規則な塊状であ る。第 1 鉱体は上記緑青沢下流付近における向斜褶曲の 軸に沿い走向 $350 \mathrm{~m}$, 傾斜方向に $650 \mathrm{~m}$, 平均厚さ $40 \mathrm{~m}$ で あり，第 2 鉱体は上記背斜構造の軸に沿つて走向に 300 $\mathrm{m}$, 傾斜方向に $400 \mathrm{~m}$, 厚さ $20 \mathrm{~m}$ であり,さらに西側の向 斜軸に沿つた第 3 鉱体㧍よび第 4 鉱体のほか, 朝日坑, 天宝坑, 千才坑方面にもスカルン帯の中に小鉱体が散在 している。

鉱床の構成金属鉱物は，黄銅鉱，磁鉄鉱を主体とし， 灭重石, 磁硫鉄鉱, 黄鉄鉱, 方鉛鉱, 閃亚鉛鉱, 輝水鉛 鉱, 輝コバルト鉣等を随伴する。スカルン鉱物としては 柘榴石, 緑篻石, 透輝石, 珪灰石, バビングトン石, 石 英，方解石等がある。（第 1 図参照）

\section{3. 採掘 法}

八茎鉱山の採掘法はサブレベルストーピングを採用し ている。採掘にあたつては，まず鉱体を垂直に $50 \mathrm{~m}$ 間隔 で区切り，各レベルには鉱体の下艋際に鉱体の走向とほ ぼ平行に運搬坑道を掘さくし，運搬坑道より $40 \mathrm{~m}$ 間隔で 鉱体中に立入坑道を掘進, 立入を中心に幅 $10 \mathrm{~m}$ の垂直鉱 柱を設け，さらに鉱体の厚い230 $180 \mathrm{~mL}$ Lは厚さ $10 \mathrm{~m}$ の水平鉱柱を, 鉱体の収縮している $180 \mathrm{~m}$ L以下では幅 $10 \mathrm{~m}$ のシルピラーを設けている。これらの鉱柱で区画さ れた鈗体鉣画とし，採掘はこの鉱画内で展開する。

\section{$3 \cdot 1$ 採掘法の変遷}

鉱体が厚く大規模な鉱画の採掘法は, 開山以来現在に 至るまで，主として下向平行半長孔によるサブレベルス トーピングを採用しているが，一部には鉱体，盤の状況 に応じて搨形長孔サブレベルストーピングを併用してい る。

薄層緩傾斜の採掘法は, 当初斜坑切羽方式を採用して いた。この採掘法は積込方式が現在のサブレベルストー ピングと異なる。すなわち, スクレーパ坑道, ドローホ 一ルを設置せず，起研鉱石は採掘跡の斜面にストック し，3胴スラッシャで搔きおろし坑井に積込む。採掘は 現在のサブレベルストーピングと同じである。この採掘 方法ではドローホールを掘さくしないので切羽準備費も 安く，準備期間も短かくて済むが，積込夫が中割および
小割作業，ワイヤー整備の際に採掘跡への立入を余儀な くされる等保安上好ましくない点もあるので，39年以降 はドローホール方式に切換えている。新方式ではスクレ 一パ坑道, ドローホールを下盤中に掘さく, アンダーカ ットレベルで鉱体に達するように設計し，アンダーカッ トレベルからの上向長孔採掘法を実施している。また鉱 体の厚さが $4 \mathrm{~m}$ 以下の高品位帯の採掘には残柱式採掘法 を採用している。

\section{$3 \cdot 2$ サブレベルストーピング採用の理由}

当鉱山の鉱体は，上盤が石灰岩，下盤が粘板岩で岩質 は一般に堅硬であり，特に上盤が石灰岩であることは採 掘跡の保持に好都合で, 断層, 破砕带, 貫入岩脈も少な， くまた坑内涌水も極めて少なく，かつスカルン帯自体も 上盤側はへデンベルグ輝石の堅い岩石であること。スカ ルン帯の規模は, 平均厚さ $20 \mathrm{~m}$, 最大厚さ $100 \mathrm{~m}$ に達し, 走向，傾斜双方に対し膨縮が多いが，全体的に $30^{\circ} \sim 45^{\circ}$ の緩傾斜をなしており，スカルン帯とその上下盤の境界 ははつきりしている。これらの鉱床賦存状況から下記理 由に基いて，サブレベルストーピングを採用することに した。

（a）鉱体の上下盤が比較的堅硬であり，過去に稼行 された採掘跡の状態と照合して一次採掘跡は無充填で保 持できる。

（b）鉱体は比較的ま之まつた塊状鉱床で，その規模 は平均厚さ $20 \sim 30 \mathrm{~m}$, 最大 $50 \sim 60 \mathrm{~m}$ に達しサブレベルス トーピングによる採掘が可能である。

(c) 高能率で低原価である。

（d）サブレベル，スクレーパー積によつて積込能率 向上, 大量集中生産が可能。

（e）さく岩作業は安全な地山内で作業できるので保 安上からも有利。

\section{$3 \cdot 3$ サブレベルストーピングの現況}

（1）切羽準備 鉱画内の精查ボーリングで鉱床の 賦存状況を確認した後, 採掘準備として運搬坑道, 坑井 切上り, スクレーパ坑道, ドローホール, サブレベル, スロット等の位置を決定し掘さくする。運搬坑道レベル と鉣体の賦存位置によつて鉱車直積にするか, 坑井積に するかが決定する。運搬坑道は $3.0 \mathrm{~m} \times 2.5 \mathrm{~m}$ の加背で掘 進,ズリ取りにはローダーを使用している。スクレーパ坑 道は鉱画のほぼ中央に $3.0 \mathrm{~m} \times 2.0 \mathrm{~m}$ の加背で, 各サブレ ベル掘進は $2.0 \mathrm{~m} \times 2.0 \mathrm{~m}$ の加背で掘進し，10Hまたは 18 Pスラッシャを使用するスラッシャレッグ方式である。 サブレベルの配置は，1段サブレベルをスクレーパ坑道 レベルより上部 7 9 $\mathrm{m}$ の所とリアンダーカットレベル とする。順次上部に実厚さ $7 \mathrm{~m}$ の間隔をもつて 2 段， 3 段，4段サブレベルを鉱体の厚さに応じて掘さくする。 坑井切上り，人道切上りは $2.7 \mathrm{~m} \times 1.5 \mathrm{~m}$ の加背で掘進, 


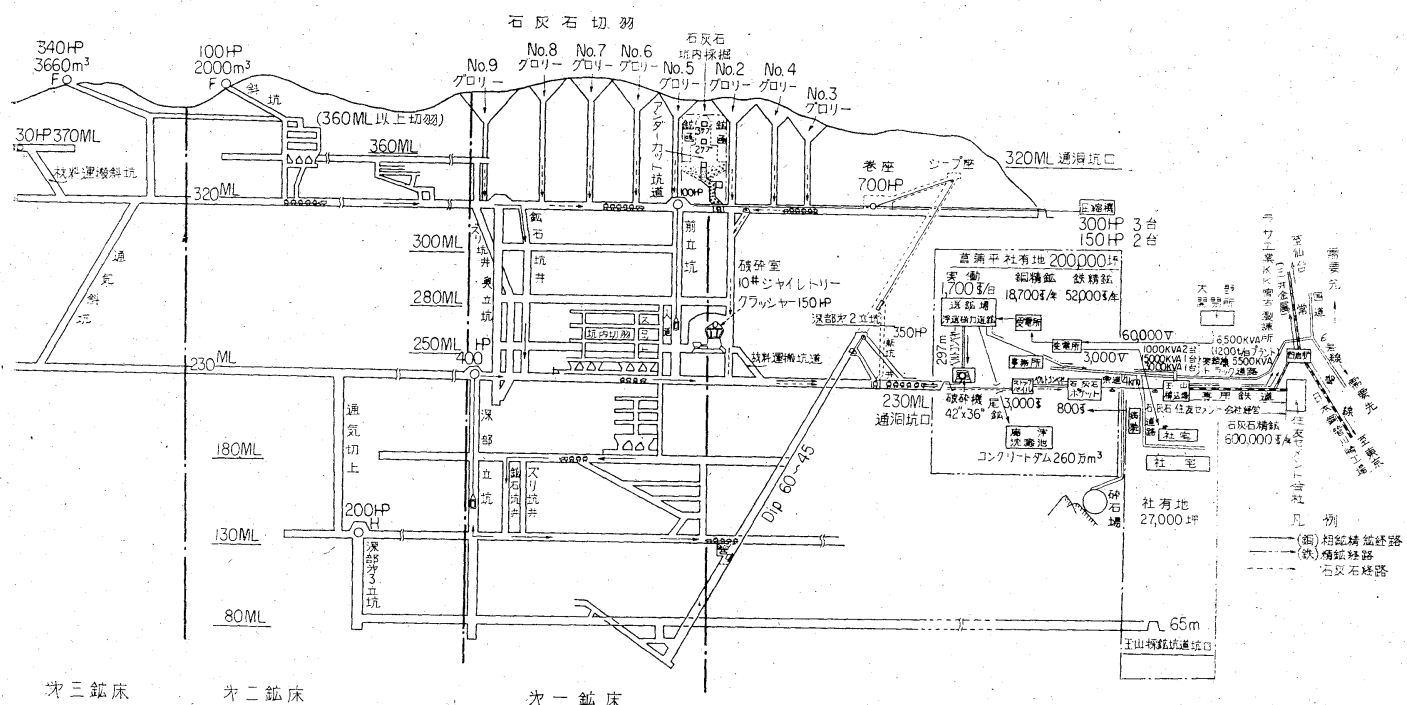

第 2 図 八茎鉱業所（銅鉱，鉄鉱，石灰石，砕石）作業䒺統図

入道切上りは各サブレベルへの人道のほかに, 切羽への 通気，材料運搬にも使用する。ズロットは採掘の際に長 孔発破の自由面とするもので, $1.8 \mathrm{~m} \times 1.5 \mathrm{~m}$ の加背で掘 進し各サブレベルに連絡する。

上記掘進作業の人員配置は各切羽とも2 名である。ド ローホールはスクレーパ玾道に起碎鉱石を抜き出すをの で,スクレーパ坑道レベルと1段サブレベルとの間に掘 さくする。(第 2 図参照)

（2）採掘 (穿孔, 発破) 採掘作業は, 根切, ズ リは数, 長孔穿孔, 長孔発破の順にくり返し行なわれる。 最初にスロットまわりを根切して長孔穿孔のベンチを作 成する。ズリはね従来手はねであつたが，アリロボ， エアーブル，10Pスラッシャ等を使用し，機械化してい る。長孔はライトドリフターによつてスロットを中心に 垂直下向平行孔を穿孔し発破する。以下根切，長孔をく り返し各サブレベルを下段より順次拡大していく。長孔 発破の規模は $3,000 \sim 10,000 \mathrm{t}$ 位である。孔長平均は $6 \mathrm{~m}$ で穿孔配置は，スロットまわり第 1 回目は 1 列目の最少 抵抗線 $1 \mathrm{~m}$ ，孔間隔1. $2 \mathrm{~m}, 2$ 列，3列目の抵抗線を 1.2 $\mathrm{m}$, 孔閒隔 $1.4 \mathrm{~m}$ とし, 第 2 回目加ら抵抗線 $1.5 \mathrm{~m}$, 孔閒隔1.8２m と大きくしている。穿孔機械は T Y 145 Dで, アリロボ使用切羽ではアリロボにさく岩機を乘駕 してワンマンッードリルを採用し, 長孔穿孔能率の向上 に努めている。穿孔径は $42 \mathrm{~mm}$ を主とし，一部で $36 \mathrm{~mm}$ の穿孔試験を実施している。爆薬は水孔以外はすべてA $\mathrm{N}-\mathrm{FO}$ を使用，採掘に沶けるAN-F O使用率は85 90 \%である。長孔発破はM. S 雷管 (段差20ミリセコンド) 使用による電気発破である。上記下向行長孔の他扇形長 孔を併用しているが，これには 41 年 5 月より $\mathrm{KH}-80$ を 使用し採掘能率と可採率の向上に寄与している。

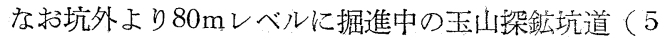
$\mathrm{km})$ にはバンカートレーンを使用している。

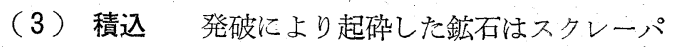
坑道にドローホールを通して落し，30 50Hの電動スラ ッシャ一にて直接鉱車に積込む加，坑井を通して鉱車に 積込む。切羽の人員配置は, 鉱車直積の場合 2 名, 坑井 積の場合 1 名である。積込能率は 42 年 3 月の実績では鉱 車直積で 1 人 1 方当り $60 \mathrm{t}$, 坑井積で $90 \mathrm{t}$ で女る。

(4) 充填 当鉱山は開坑以来日も浅人, 採掘は 37 年までは専ら一次採掘のみ実施してきたが，38年 9 月，以 降一次採掘終了箇所に抒いて二部二次採掘（水平鉱柱） を開始した。これと併行して坑外廃㳯ダム延命, 坑内充 塡による二次採掘（垂直鉱柱）を目的としたスライム充 塡を計画, 種々試験, 研究を重叔 42 年 2 月より坑内採掘 跡への放泥試験を開始した。. 42 年 3 月の釷体別出鈗実績 を第 3 表，採掘原単位を第 4 表，開山以来の年間粗鈗生

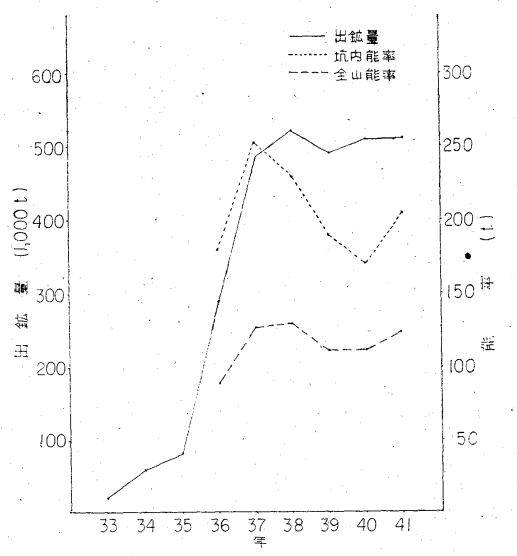

第 3 図 
第 3 表 鉱体別出鉱量および切羽数

(昭和 42 年 3 月実蹟)

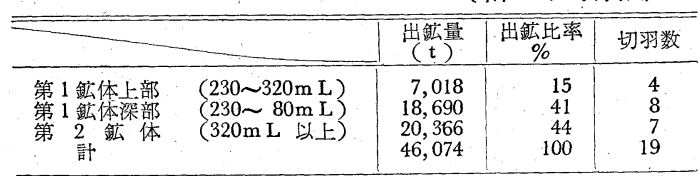

第 4 表，採掘原単位 （昭和 42 年 3 月矣績）

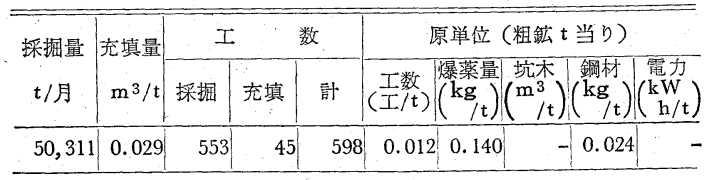

第 5 表 年間出鉱量, 平均品位抒よび能率の推移

\begin{tabular}{|c|c|c|c|c|c|}
\hline & \multirow{2}{*}{$\begin{array}{c}\text { 年間出鉱量 } \\
(\mathrm{t})\end{array}$} & \multicolumn{2}{|c|}{ 平 均 品 位 } & \multicolumn{2}{|c|}{1 人 1 力月当出釷量 } \\
\hline & & $\mathrm{Cu} \%$ & $\mathrm{Fe} \%$ & 坑内 $(t)$ & 全山 $(t)$ \\
\hline $\begin{array}{l}32 \text { 年 } \\
33 \\
34 \\
35 \\
36 \\
37 \\
38 \\
39 \\
40 \\
41\end{array}$ & $\begin{array}{r}18,496 \\
62,118 \\
82,725 \\
288,170 \\
484,219 \\
522,319 \\
493,347 \\
513,894 \\
510,660\end{array}$ & $\begin{array}{l}1.38 \\
1.27 \\
1.15 \\
1.03 \\
0.85 \\
0.81 \\
0.80 \\
0.80 \\
0.80\end{array}$ & $\begin{array}{l}5.65 \\
5.53 \\
5.68 \\
3.85 \\
4.51 \\
5.04 \\
5.70 \\
6.36 \\
5.05\end{array}$ & $\begin{array}{r}\overline{-} \\
\overline{-} \\
179 . \overline{2} \\
254.1 \\
231.0 \\
190.0 \\
173.0 \\
207.0\end{array}$ & $\begin{array}{r}\bar{z} \\
\overline{\overline{ }} \\
88 . \overline{7} \\
127.1 \\
131.0 \\
112.0 \\
11.0 \\
124.0\end{array}$ \\
\hline
\end{tabular}

産量, 平均品位および能率 (坑内, 全山) の推移を第 5 表, 第 3 図に示す。

\section{4. 運一搬}

当所の運搬系統は第 2 図に示す通りである。運搬系統 の主動脈は，230m Lに掘さくした暮蒲平通洞で延長約 $1,500 \mathrm{~m}$, 加背 $4.3 \mathrm{~m} \times 2.5 \mathrm{~m}$, ゲージ $610 \mathrm{~mm}$ の複線坑道 で鈗石, ズリ, 人員, 材料一切の運搬に充当している。入 出坑線には点制御自動閉塞方式の信号を設置し, 列車が $450 \mathrm{~m}$ の 間隔を確保するようにし, 追突事故防止洨果 をあげている。また坑口には，列車が坑口より $200 \mathrm{~m} の$ 位置に来たら警報を発する列車自動検出装置を設置して いる。その他分岐籄所には自家製シリンダーによる自動 ポイントを設置している。運搬での使用機器は $2.3 \mathrm{~m}^{3}$ グ ランビー鉱車, $10 \mathrm{t}$ トロリーロコ, $4 \mathrm{t}$ バッテリーロコ 等である。

第1 鉱体上部 $(230 \sim 320 \mathrm{~m} \mathrm{~L})$ の起硴鉱石は, $230 \mathrm{~m} \mathrm{~L}$ のスラッシャ一地並に落し, 直積または坑井積にて鉱車 に積込む。第 2 鉱体 $(320 \mathrm{~mL}$ 以上) の鉱石は, 奥立鉱 石坑井を通して $230 \mathrm{~m}$ Lに落し, 通洞地並以下の鉱石は $130 \mathrm{~mL}$ L集め, 鉱石專用の第 2 立坑スキップ巻 $(350 \mathrm{HP})$

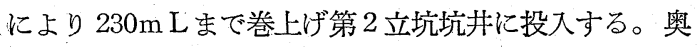
立, 第 2 立坑坑井の鉱石は $230 \mathrm{~m} \mathrm{~L}$ にて $10 \mathrm{t}$ トロリーロ コを使用し，上部の鉱石と共に主要運搬坑道に集め, 通 洞を経て坑外へ搬出している。 $230 \mathrm{~mL}$ 以外の各レベル での運搬には総て $4 \mathrm{t}$ バッテリーロコを使用している。 第 1 鉱体上部および第 2 鉱体のズリ処理は鉱石の場合と
同様であるが, $230 \mathrm{~m}$ L 以下のズリは深部立坑巻 $(400 \mathrm{PP})$ にて $230 \mathrm{~mL}$ ○巻上げ玾外へ出す。人員注第 1 鉱体では 菖蒲平通洞上り入坑し, 前立坑, 深部立坑を経て切羽に 行く。第 2 鉱体は $320 \mathrm{~mL}$ Lり入坑する。材料も人員々 同じ経路で切羽へ搬入している。

\section{5. 通気, 排水, 照明, 保安}

\section{$5 \cdot 1$ 通 気}

当所の通気は, 開発当初は坑内の拡が方も狭く切羽も $230 \mathrm{~mL}$ 以上であり，自然通気で作業にそれほぞ支障はな かつた。しかし36年生産開始以来, 坑内発展む急速に進 み, 切羽の主体も深部に移行し始め, さらに積込の爆薬 使用䇢所の増加等により自然通気のみによつて所要通気 量を確保することは不可能となり，36年に第 1 次通気改 善計画を立案， 37 年に完成し $75 \mathrm{~kW}$ (最大風圧 $90 \mathrm{~mm}$ 水 柱, 風量 $2,500 \mathrm{~m}^{3} / \mathrm{min}$ ) の扇風機が運転を開始した。引 続き第 2 次改善計画 (長期計画) を立案， 40 年10月に完 成し新たに $255 \mathrm{~kW}$ (風圧 $152 \mathrm{~mm}$ 水柱, $3,320 \mathrm{~m}^{3} / \mathrm{min}$ ) の主要扇風機が運転開始するにおよび通気の合理化も完 成し，八茎鉱山の通気体系が出来上つた。切羽末端部， 局部的停滞部分の気流確保には，局部扇風機，風管，工 アームーバー等を, 不要な気流のしゅ断や通気量調節に は風門，ビラ門等を使用している。

\section{$5 \cdot 2$ 排 水}

当所の場合坑内湧水は少なく, $230 \mathrm{~m} L$ 以上は 自然排 水であり， $230 \mathrm{~mL}$ L下はポンプで揚水し，以後は通洞 を経て自然排水している。ボンプは総て自動運転であ る。現在鋭意掘進中の玉山探鉱坑道が既設 $80 \mathrm{~mL}$ 亿貫通 後は，玉山坑道を排水坑道とした自然排水方法となる。

\section{$5 \cdot 3$ 照 明}

坑内主要設備 (立坑プラット, 巻上, 休息場, コンプ レッサー室) や主要運搬坑道には螢光灯および白熱電灯 を使用し, 採掘, 掘進, 積込の各切羽に注 $300 \mathrm{~kW}$ の投光 器を備えて切羽照明を行なつている。作業者は全員キャ ップランプを使用している。

\section{4 保 安}

当所における過去の災害事例では墜落, 浮石の落下, 運搬等の事故が大半を占めているので，これらによる災 害防止に特に留意してきた。墜落については必ず簡易鉄 柱をスロットまわりに立て、ロープを張るように教育指 導し現在では完全に実施されている。浮石については作 業開始前の点検, 処理のほか午前, 午後に各 1 回浮石点 検時間を設け,合図と共にいつせいに仕事を一時中止し， 周囲の浮石を点検することにしている。運搬については, 主要運搬坑道にはもれなく信号を設置し, 運転, 先乗の 教育，指導を強化し災害防止につとめている。このほか 現場での保安教育, 保安愁談会を月 1 回以上実施し, 無 
災害事故報告運動を推進することにより保安意識の高揚 につとめた結果，最近は災害件数も激減し，保安成績も 向上している。

\section{6. 問題点之将来計画}

八茎鉱山も開山以来10年を経て, 坑内発展も急速に進 み, 今後さらに採掘区域の桩大, 深部移行は必至であり, 粗鉱品位も若干低下寸る傾向にある。これらによる運搬
費の増加，労務費の逐年上昇，銅建値の変動等に対応し 生産コストの節減をはかるべく長期合理化計画を立案, 実施中である。すなわち坑内作業の機械化および圧気上 昇による能率向上, AN-FO 使用率の向上, 低品位合 理化工事 (増産体制) の推進等である。さらに可採鉱量 の増加を図るためスライム充䁲, 二次採掘を検討中であ り，スライム充増はすでに開始している。

\section{都茂鉱山}

Tsumo Mine

\section{1. 緒言}

位置 : 島根県美濃郡美都町大字山本に鉱業所事務所が 㐫る。山陰本線益田駅と事務所間は $20 \mathrm{~km}$ で, バスおよ びトラックが通つている。

沿革 : 都茂鉱業所には都茂坑と丸山坑とがあり, 都茂 坑は明治26年頃発見，丸山坑は武家時代に発見稼行され たという。昭和13年都茂鉱山株式会社の所有となり，昭 和18年 1 月興亜鉱業株式会社の経営となり，戦時中 $30 t /$ 日の浮遊選鉱場を設置し，フロスは日比および佐賀関に 売鈗した。250t/日 浮遊選鉣場の設立に着手したが建設 途上で終戦となり設立しなかつた。昭和 23 年協和鉱業株 式会社により再開され，昭和 26 年 8 月中外鉱業株式会社 で買収し，浮遊選釷場を修理復旧し，30t/日処理より順 次增産し，昭和41年4月には $250 \mathrm{t} /$ 日 浮遊選鉱場を完成 し, さらに増産体制を整え, 現在 $300 \sim 310 t /$ 日処理操業 である。

現状 : 昭和 42 年 3 月の粗鉱量, 品位, 従業員数等の実 績は別表第 1 表のとおりである。都茂坑は既知鉱体 の採掘を終了し，探鉱を行なつており，丸山坑は採掘お よび探鉱を行なつており，粗鉱を丸山坑で賄つている。

過去10年間の年間出鉱量平均品位および能率の推移は 第 5 表，第 1 図の通りである。

\section{2. 地質鉱床の要約}

地質は粘板岩，砂岩，珪岩，緑色岩および石灰岩等よ りなる古生層中に, 閃緑岩, 石英斑岩, 玢岩, 花崗岩等 の貫入があり，複雑な褶曲および断層を伴なつて構成さ れている。都茂，丸山地区のほぼ中央部には断層を伴な

* 中外鉣業株式会社都茂鉱業所

正会員小茂*

Shigeru KOGISO

第 1 表 粗鈗量々出 鉱品位

\begin{tabular}{c|c|c}
\multicolumn{3}{c|}{ 鉱品位 } \\
\hline 粗鉱 量 & 品 & 位 $(\%)$ \\
\hline$(\mathrm{t})$ & $\mathrm{Cu}$ & $\mathrm{Zn}$ \\
\hline 7,885 & 1.14 & 0.97
\end{tabular}

第 2 表 従業員

\begin{tabular}{|c|c|c|c|}
\hline & 坑 内 & 坑 外 & 訫 \\
\hline $\begin{array}{l}\text { 職 員 } \\
\text { 徒賞 } \\
\text { 䠛 時 } \\
\text { 計 }\end{array}$ & $\begin{array}{r}9 \\
54 \\
63 \\
126\end{array}$ & $\begin{array}{r}20 \\
45 \\
9 \\
74\end{array}$ & $\begin{array}{r}29 \\
99 \\
72 \\
200\end{array}$ \\
\hline
\end{tabular}

第3 表 採掘法別出鉱量掞よび切羽数

\begin{tabular}{|c|c|c|c|}
\hline 採描法の種 類 & 出鉱量 $(t)$ & 出鉱比率 $(\%)$ & 切羽 数 \\
\hline 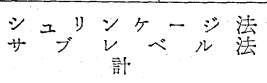 & $\begin{array}{l}1,400 \\
6,085 \\
7,485\end{array}$ & $\begin{array}{r}19 \\
81 \\
100\end{array}$ & $\begin{array}{r}3 \\
10 \\
13\end{array}$ \\
\hline
\end{tabular}

第4 表 開探鉱出鉱量打よび試錐延長

\begin{tabular}{|c|c|c|c|c|}
\hline 試 錐 延 長 & 探開延長 & 出 & 鉣 & $(t)$ \\
\hline$(\mathrm{m})$ & $(\mathrm{m})$ & 開探 鉱 & 採 & 計 \\
\hline 71 & 42 & 400 & 7,485 & 7,885 \\
\hline
\end{tabular}

第 5 表 過去10年間の年間出鉱量 平均品位括よび能率 (坑内, 全山) 推移

\begin{tabular}{|c|c|c|c|c|c|}
\hline & \multirow{2}{*}{$\begin{array}{c}\text { 年間出鉱量 } \\
(\mathrm{t})\end{array}$} & \multicolumn{2}{|c|}{ 平均品位 $(\%)$} & \multicolumn{2}{|c|}{1 人 1 月当出鉣量 } \\
\hline & & $\mathrm{Cu}$ & $\mathrm{Zn}$ & $(t)^{\text {坑 }}$ & 全 $(\mathrm{t})^{\mu}$ \\
\hline $\begin{array}{l}32 \text { 年 } \\
33 \\
34 \\
35 \\
36 \\
37 \\
38 \\
39 \\
40 \\
41 \\
\text { 訣 } \\
\text { 平坞 }\end{array}$ & $\begin{array}{r}18,696 \\
20,649 \\
22,614 \\
29,208 \\
35,703 \\
35,698 \\
27,215 \\
33,601 \\
43,632 \\
74,222 \\
341,338 \\
-\end{array}$ & $\begin{array}{l}0.61 \\
0.59 \\
0.71 \\
0.65 \\
0.60 \\
0.65 \\
1.21 \\
0.98 \\
1.05 \\
1.15 \\
0.88\end{array}$ & $\begin{array}{r}6.13 \\
5.67 \\
4.29 \\
3.51 \\
4.73 \\
4.25 \\
1.69 \\
3.82 \\
3.12 \\
1.05 \\
3.35\end{array}$ & $\begin{array}{r}30.5 \\
32.7 \\
37.7 \\
41.1 \\
51.5 \\
51.5 \\
47.9 \\
49.7 \\
61.5 \\
65.2 \\
. \\
-\end{array}$ & $\begin{array}{r}13.1 \\
14.4 \\
16.5 \\
19.4 \\
24.6 \\
24.7 \\
22.2 \\
21.7 \\
23.5 \\
33.7 \\
-\end{array}$ \\
\hline
\end{tabular}

つた背斜構造が認められ，背斜軸に沿つて石英斑岩の大 きな岩脈が分布する。

主要鉱床はこの背斜軸の北部に都茂鉱床, 南部に丸山 鉱床があつて，それぞれ相対して存在する。鉣床は褔曲 